\title{
LEISURE-TIME BEHAVIOUR OF SENIORS IN OPAVA REGION IN THE CONTEXT OF THE PROBLEMS OF SOCIAL EXCLUSION
}

\author{
Kamil Janiš Jr.
}

\begin{abstract}
This paper deals with selected data of the leisure-time behaviour of elderly people from a regional research which are commented in regard or social exclusion. The objective of the contribution is mainly to point out the possible risks arising in its subject matter area. The structure of the paper intentionally does not provide space for an operationalization of the fundamental concepts, taking into account the excessive complexity and disproportionate scope of the text. The basic concepts are only defined.
\end{abstract}

\section{Keywords}

leisure-time of seniors, senior, social exclusion

\section{Introduction}

Seniors in the Czech Republic are a group undoubtedly affected by social exclusion. This sentence can be heard in the media, read in the newspapers, read on news sites in the Internet, heard from the mouths of politicians during electoral meetings, etc. It has to some extent become what can be described as a cliché - unfortunately. The combination of the words "social exclusion" and "senior" is usually equated with the issues of the level (or low level) of retirement pensions, housing, illnesses in the senior age, ageism in the Czech society, etc. The author of this paper, however, focuses on the issues of the leisure-time behaviour of the elderly in the context of the area of their social exclusion. Due to this aspect, some areas are deliberately given no wider and deeper attention.

\section{The Definition of Basic Concepts}

Basic concepts to be operated below are leisure-time of seniors, senior and social exclusion. Part of the text marked as Chapter 1 is deliberately named "The Definition of Basic Concepts" and not "The Operationalization of Basic Concepts". Although an operationalization would be more correct 
methodologically, only the term "leisure time of seniors" would take a disproportionate amount of text, and therefore for and overall understanding of the subject area, cf. - Janiš Jr., 2011; Janiš Jr., 2012a; Janiš Jr., 2012b; Janiš Jr., 2013c; Janiš Jr., 2014¹.

In this paper, leisure time is defined and understood according to the residual definition of free time. "The leisure time of seniors is such time when activities of interest are carried out on the basis of physical, psychological and interest based aspects of individual persons, being carried out apart of the time devoted to the care for their own persons, households, families and the satisfaction of their individual basic senior-age needs. These are the sort of activities that bring joy, entertainment, contentment, pleasure and satisfaction." (Janiš Jr., 2011, p. 694).

A person that can be described as a senior can be described in a disproportionately easier way than the concept of free time of seniors. This paper considers as seniors persons who have reached the age of 65 years or more. The age limit fulfils the function of arbitrariness and therefore does not reflect other possible characteristics or other aspects, which would make it possible to regard a person as a senior (Janiš Jr., 2012a).

The concept of social exclusion is defined in the Social Services Act, no. 108/2006 Coll., Section 3 Subsection $\mathrm{f}$ ): social exclusion shall mean exclusion of a person from a common life within the society and impossibility of integration into such life due to an adverse social situation. This is, however, a so-called. "circular definition," i.e. it does not provide a precise delimitation of the concept of social exclusion in the context of this paper.

The Agency for Social Inclusion characterizes social exclusion as follows: "To put it simply, socially excluded citizens are those who have restricted access to institutions and services (i.e. institutional assistance), excluded from the social networks and do not have enough vertical contacts outside the socially excluded locality. The basic characteristic of the decline to the bottom of the society is the accumulation of reasons that lead to a life crisis (loss of employment, inability to repay, problems with housing, problems of children in school, illness, etc.). Socially excluded people usually do not face a single problem but a complex group of problems where usually one of them alone would jeopardize the normal functioning of a human being in the society. With the gradual descend to the bottom, it ceases to be clear what the original reason for the downturn was and what is only its result." (http://www.socialni-zaclenovani.cz/co-je-socialni-vylouceni [Czech])

In connection with the elderly, it is essential not to speak only about social exclusion in general, but also about social isolation. However, these are not synonyms as it is sometimes presented (e.g. by the Senior in Ostrava company). Social exclusion in itself implements social isolation.

Percy-Smith (2010 in Mareš, Sirovátka, 2008, s. 274-275) distinguishes several dimensions: "the economic dimension (long-term unemployment, low income and income poverty...), the social dimension (breaking the traditional household and marriage breakups, social isolation, homelessness, a variety of socio-pathological phenomena such as crime, unwanted teenage pregnancies...), the political dimension (the denial of political rights, inability to participation, low participation in elections...), the community dimension (devastated environment and dwellings, inaccessibility of

\footnotetext{
${ }^{1}$ The most detailed and most comprehensive operationalization of the fundamental concepts which is supplemented by a theoretical basis for the leisure-time behaviour of seniors can be found in the publication - Janiš Jr., K., \& Skopalová, J. (2016). Leisure Time of Seniors. Prague: Grada.
} 
services, collapse of supporting network...), the individual dimension (physical or mental handicap or illness, lack of education and skills, loss of self confidence and self esteem...), the group dimension (the concentration of the listed exclusion characteristics in certain social groups), and the spatial dimension (the concentration of the excluded in areas with accumulated risk factors and without a corresponding quality of life: crime, poor environment, poor transport and infrastructure, poor quality of civic amenities, including schooling and healthcare....)."

Two definitions of social exclusion have been listed. However, the above dimensions are of more substance to the purposes of this paper because the issues of social exclusion of the elderly in the context of their leisure-time behaviour can be better specified by it and can lead to more relevant conclusions.

\section{Research Methodology}

The results of the research have been and are part of the author's dissertation named Leisure Time of Seniors and so far have not been published. With reference to the original objectives of the research, the results are not listed below as they are not related to the thematic focus of this paper. Therefore, the author does not mention the research questions, hypotheses and their verification. The complete results of the research occupy 63 pages and therefore are presented in a thematically and relationally corresponding partial section. The data were obtained through a questionnaire of own design. In this paper, the author uses secondary data analysis.

\subsection{The Selection of Respondents}

The sample of respondents was primarily determined by the greatest possible degree of randomization of the selection of individual seniors. The fundamental criterion was the place of residence ("own" home or a residential facility). All responding seniors were fully or partially mobile, i.e. not bedridden, and could perform some kind of physical leisure activity, albeit adapted to their health status (current or long-term).

Justification of non-inclusion of other criteria:

1. Education - The achieved level of education may not be a relevant indicator, mainly on the grounds that some seniors did not have the opportunity to study in the years 1938-1945 and 1948-1989. Furthermore, they could not study for existential reasons (the need to go to work), due to the lack of university capacities, etc. It is therefore not clear whether the level of education constitutes a relevant indicator for the realization of leisure activities of seniors.

2. Proportionality according to sex - The author could not fulfil this criterion without utilizing the available or deliberate (quota) selection ${ }^{2}$. The author was strongly dependent on the willingness of the elderly to cooperate. Furthermore, the sex ratio of seniors living in residential facilities does not correspond with the sexual composition of the basic population. The author was also significantly limited by the willingness of seniors to respond.

\footnotetext{
${ }^{2}$ Even if that would be acceptable.
} 
3. Proportionality by age - The same reason as given above.

4. Breakdown by place of residence (village, town) - This criterion was originally considered. However, it was rejected on the grounds that it should rather form the basis of a separate research project. Particularly among the elderly people living in residential facilities in the country, this would have to be an exhaustive selection, which is unrealistic or so.

Selection and characterization of respondents living at home: The municipalities in the Opava district were divided into two groups - the towns and villages ${ }^{3}$. Subsequently, a random selection through a drawing attended by a witness was carried out to select 4 towns and 6 villages. Individual seniors were then contacted through people known to them. The author wanted to eliminate the subjectivity of the selection of respondents. Of the 148 respondents polled, only 29 men were willing to cooperate. The average age of these men was 74.54 years, standard deviation was 5.95 and the median 74 . The youngest respondent was 65 years old and the oldest 91 years old 4 .

Also, 119 women took part in the survey. The average age of these women was 73.41 years, standard deviation was 5.32 and the median 73 . The youngest respondent was 65 years old and the oldest 85 years old. Based on these data, we can say that men and women were balanced in terms of age groups. The overall average age was 73.64 years, standard deviation was 5.40 and the median 73 .

Selecting respondents living in residential facilities: Residential facilities were retirement homes for seniors or nursing homes. Residential facilities were chosen irrespective of the nature of their founder. The procedure was the same as above -6 facilities were chosen through the drawing.

Of the 110 respondents polled, only 10 men were willing to cooperate. The average age of these men was 77.80 years, standard deviation was 7.02 and the median 79 . The youngest respondent was 65 years old and the oldest 88 years old ${ }^{5}$.

Also, 100 women took part in the survey. The average age of these men was 79.68 years, standard deviation was 7.19 and the median 81 . The youngest respondent was 65 years old and the oldest 100 years old.

The group of respondents living in residential facilities have a naturally higher age average. The selection of individual respondents in each facility was completely left in the hands of the responsible personnel. The only instruction to them was that they were to approach "various" seniors, not just those "active".

The seniors did not sign informed consent declarations. The polled seniors knew they were being surveyed. Thus, by filling out the questionnaire or participating in the interview, they were giving their consent to the research. They all knew the purpose of research and its utilization (Švaříček, Šed'ová et al., 2007; Gavora, 2006).

The total number of respondents, 258, can be described as relatively low. The determining factor in the low numbers was the un/willingness of the seniors to fill out a questionnaire. Author did not meet with any verbal aggression on the part of seniors, however, some rather strict refusal to fill in the ques-

\footnotetext{
${ }^{3}$ The only township in the Opava district are Litultovice. They were assigned to the category of villages.

${ }^{4}$ The age may be slightly misleading. For the sake of data anonymization and to increase the credibility, the question of age was for the age the respondent was to reach in 2013. In theory, the true age may be less than a year lower.

${ }^{5}$ The average age of men was influenced mainly by two values: 65 and 68 years; as these values significantly distort the average in relation to the overall low frequency.
} 
tionnaire was encountered. Although seniors living at home were contacted through people known to them, they were not willing to participate in the survey. In the above group of seniors, a partly surprising finding was that although mainly married couples were approached, men refused to fill the questionnaire more often than women. That is the reason of the low number of male respondents. Seniors were contacted from January to April 2013.

\section{Research Results}

As mentioned above, the data presented below are not the complete research data. However, the data are presented not only in absolute and relative frequencies (relative frequencies are shown in the upper right corner of each table field), but they are also complemented with the Pearson's chi-squared test and its interpretation. For data where it was purposeful, the commented coefficient contingency is also calculated.

Question: From the age of 65, I try to spend my leisure time primarily doing physical activities.

\begin{tabular}{|c|c|c|c|c|c|c|c|c|c|c|c|}
\hline \multirow{3}{*}{$\begin{array}{c}\text { Seniors - } \\
\text { Domestic Environment }\end{array}$} & \multicolumn{2}{|c|}{$\begin{array}{l}\text { Definitely } \\
\text { Yes }\end{array}$} & \multicolumn{2}{|c|}{$\begin{array}{l}\text { Rather } \\
\text { Yes }\end{array}$} & \multicolumn{2}{|c|}{$\begin{array}{l}\text { Do not } \\
\text { Know }\end{array}$} & \multicolumn{2}{|c|}{$\begin{array}{l}\text { Rather } \\
\text { Not }\end{array}$} & \multicolumn{2}{|c|}{$\begin{array}{l}\text { Definitely } \\
\text { Not }\end{array}$} & \\
\hline & 26 & 17.57 & 34 & 22.97 & 31 & 20.95 & 32 & 21.62 & 25 & 16.89 & \multirow{2}{*}{148} \\
\hline & & & & & & & & & & & \\
\hline \multirow{2}{*}{$\begin{array}{c}\text { Seniors - } \\
\text { Residential Facility }\end{array}$} & \multirow{2}{*}{11} & 10 & \multirow{2}{*}{22} & 20 & \multirow{2}{*}{25} & 22.73 & \multirow{2}{*}{20} & 18.18 & \multirow{2}{*}{32} & 29.09 & \multirow{2}{*}{110} \\
\hline & & & & & & & & & & & \\
\hline \multirow{2}{*}{$\boldsymbol{\Sigma}$} & \multirow{2}{*}{37} & 14.34 & \multirow{2}{*}{56} & 21.71 & \multirow{2}{*}{56} & 21.71 & \multirow{2}{*}{52} & 20.15 & \multirow{2}{*}{57} & 22.09 & \multirow{2}{*}{258} \\
\hline & & & & & & & & & & & \\
\hline
\end{tabular}

Table no. 1 The frequency of physical activities

The question examined whether the seniors concentrate in their leisure time mainly on physical activity, and that mainly to foster their health. According to the wording of the question, the answer "definitely not" does not necessarily mean physical leisure-time inactivity, but of course it can.

Statistically significant differences in preference of physical leisure-time activities among groups of seniors were found for this question. The detected p-value $3.76 \times 10^{-2}$ is lower than the chosen significance level of 0.05 . We can therefore say that seniors living at home significantly more often prefer physically oriented leisure-time activities. The observed results can be attributed to lower average age of seniors living at home and to the factors arising from their environment.

Contingency coefficient $C=0.19$. It can be argued that the relationship between variables is weak. In another part of the research, among others, the author asked what "leisure time" means to the elderly. In a nutshell, it means for them the proof that they live. Especially physical leisure-time activities signify their autonomy to them and may lead to the fact that seniors do not feel socially isolated. They are not closed only in their dwelling space. However, we cannot imagine that the elderly would "have a taste for" collective exercise, demanding physical activities, etc. To some, motion leisure-time activities means simply taking walks. 
Question: I was looking forward to retirement because I would not have to get up for work ${ }^{6}$.

\begin{tabular}{|c|c|c|c|c|c|c|c|c|c|c|c|}
\hline \multirow{3}{*}{$\begin{array}{c}\text { Seniors - } \\
\text { Domestic Environment }\end{array}$} & \multicolumn{2}{|c|}{$\begin{array}{l}\text { Definitely } \\
\text { Yes }\end{array}$} & \multicolumn{2}{|c|}{$\begin{array}{l}\text { Rather } \\
\text { Yes }\end{array}$} & \multicolumn{2}{|c|}{$\begin{array}{l}\text { Do not } \\
\text { Know }\end{array}$} & \multicolumn{2}{|c|}{$\begin{array}{l}\text { Rather } \\
\text { Not }\end{array}$} & \multicolumn{2}{|c|}{$\begin{array}{l}\text { Definitely } \\
\text { Not }\end{array}$} & \multirow{3}{*}{148} \\
\hline & \multirow{2}{*}{21} & 14.19 & \multirow{2}{*}{32} & 21.62 & \multirow{2}{*}{19} & 12.84 & \multirow{2}{*}{54} & 36.49 & \multirow{2}{*}{22} & \multirow[t]{2}{*}{14.86} & \\
\hline & & & & & & & & & & & \\
\hline \multirow{2}{*}{$\begin{array}{c}\text { Seniors - } \\
\text { Residential Facility }\end{array}$} & \multirow{2}{*}{21} & 19.27 & \multirow{2}{*}{22} & 20.18 & \multirow{2}{*}{14} & 12.84 & \multirow{2}{*}{32} & 29.36 & \multirow{2}{*}{20} & 18.35 & \multirow{2}{*}{$109^{7}$} \\
\hline & & & & & & & & & & & \\
\hline \multirow{2}{*}{$\boldsymbol{\Sigma}$} & \multirow{2}{*}{42} & 16.34 & \multirow{2}{*}{54} & 21.01 & \multirow{2}{*}{33} & 12.85 & \multirow{2}{*}{86} & 33.46 & \multirow{2}{*}{42} & 16.34 & \multirow{2}{*}{257} \\
\hline & & & & & & & & & & & \\
\hline
\end{tabular}

Table no. 2 The seniors' attitudes to looking forward to retirement because of not having to get up for work

The question followed the generally accepted cliché of "looking forward" to old-age retirement, precisely because one no longer has to work. On this question, there were no significant differences between the two groups and looking forward to old-age retirement because of not having to get up for work.

The detected p-value 0.56 is higher than the chosen significance level of 0.05 . Based on the frequencies listed, one can clearly view positively the fact that both groups of seniors did "rather", or "definitely" not look forward to retirement due to not having to go to work, but a considerable part of the polled seniors were indecisive.

Although there are some differences between the two groups of seniors, the result of contingency coefficient $\mathrm{C}=0.11$ shows that there only is a weak dependence between the variables.

The acquired data can be interpreted so that their work brings the seniors considerable social contacts and a form of daily routine.

Question: I spend my leisure time doing the same activities as my friends with whom I regularly (at least once a week) meet.

\begin{tabular}{|c|c|c|c|c|c|c|c|c|c|c|c|}
\hline \multirow{2}{*}{$\begin{array}{c}\text { Seniors - } \\
\text { Domestic Environment }\end{array}$} & \multicolumn{2}{|c|}{$\begin{array}{l}\text { Definitely } \\
\text { Yes }\end{array}$} & \multicolumn{2}{|c|}{$\begin{array}{l}\text { Rather } \\
\text { Yes }\end{array}$} & \multicolumn{2}{|c|}{$\begin{array}{l}\text { Do not } \\
\text { Know }\end{array}$} & \multicolumn{2}{|c|}{$\begin{array}{l}\text { Rather } \\
\text { Not }\end{array}$} & \multicolumn{2}{|c|}{$\begin{array}{l}\text { Definitely } \\
\text { Not }\end{array}$} & \multirow{2}{*}{148} \\
\hline & 15 & 10.14 & 34 & 22.97 & 65 & 43.92 & 12 & 8.11 & 22 & 14.86 & \\
\hline $\begin{array}{c}\text { Seniors - } \\
\text { Residential Facility }\end{array}$ & 32 & 29.09 & 26 & 23.64 & 15 & 13.64 & 19 & 17.27 & 18 & 16.36 & 110 \\
\hline $\boldsymbol{\Sigma}$ & 47 & 18.22 & 60 & 23.26 & 80 & 31.00 & 31 & 12.02 & 40 & 15.50 & 258 \\
\hline
\end{tabular}

Table no. 3 Spending leisure time doing the same activities as friends

\footnotetext{
${ }^{6}$ Formulation of the questions came from preliminary research.

${ }^{7}$ In one of the questionnaires, this question was not answered. The reason was that the senior interviewed had never gone to work. She was a housewife.
} 
The results, which appear in Table no. 3, need to be viewed in a completely different way than the data above. With this question, it is necessary to sum up the nominal data into acceptable groups and verify their statistical significance with the Pearson's chi-squared test. When we test the results this way, we find statistically significant differences at the 0.05 level of significance ( $p$-value $3.41 \times 10^{-7}$ ). This value is, however, clearly influenced by the particular frequencies in the category "do not know". Adding up the frequencies in categories "definitely yes" and "rather yes" and putting them into opposition with the frequencies in categories "rather not" and "definitely not", we find that there are no statistically significant differences at the significance level of 0.05 (p-value 0.78).

We can therefore conclude that although we assume naturally better opportunities for older people in residential facilities to spend their free time with their friends on a regular basis, doing the same activities, their answers do not differ significantly from the seniors living at home ${ }^{8}$.

The above-mentioned results can already be significantly extended to the issues of social exclusion of the elderly. Although not explicitly arising from these issues, individual spending of leisure time can be a threatening or risk factor for a senior. This can, however, be interpreted as the seniors' independent decision on their leisure activities.

Question: During my leisure time, it is important to me how my family perceive my activities (what they think about them).

\begin{tabular}{|c|c|c|c|c|c|c|c|c|c|c|c|}
\hline \multirow{3}{*}{$\begin{array}{c}\text { Seniors - } \\
\text { Domestic Environment }\end{array}$} & \multicolumn{2}{|c|}{$\begin{array}{l}\text { Definitely } \\
\text { Yes }\end{array}$} & \multicolumn{2}{|c|}{$\begin{array}{l}\text { Rather } \\
\text { Yes }\end{array}$} & \multicolumn{2}{|c|}{$\begin{array}{l}\text { Do not } \\
\text { Know }\end{array}$} & \multicolumn{2}{|c|}{$\begin{array}{l}\text { Rather } \\
\text { Not }\end{array}$} & \multicolumn{2}{|c|}{$\begin{array}{l}\text { Definitely } \\
\text { Not }\end{array}$} & \multirow{3}{*}{148} \\
\hline & \multirow{2}{*}{11} & 7.43 & \multirow{2}{*}{22} & 14.86 & \multirow{2}{*}{15} & 10.14 & \multirow{2}{*}{32} & 21.62 & \multirow{2}{*}{68} & \multirow[t]{2}{*}{45.95} & \\
\hline & & & & & & & & & & & \\
\hline \multirow{2}{*}{$\begin{array}{c}\text { Seniors - } \\
\text { Residential Facility }\end{array}$} & \multirow{2}{*}{21} & 19.09 & \multirow{2}{*}{20} & 18.18 & \multirow{2}{*}{15} & 13.64 & \multirow{2}{*}{24} & 21.82 & \multirow{2}{*}{30} & 27.27 & \multirow{2}{*}{110} \\
\hline & & & & & & & & & & & \\
\hline \multirow{2}{*}{$\boldsymbol{\Sigma}$} & \multirow{2}{*}{32} & 12.40 & \multirow{2}{*}{42} & 16.28 & \multirow{2}{*}{30} & 11.63 & \multirow{2}{*}{56} & 21.71 & \multirow{2}{*}{98} & 37.98 & \multirow{2}{*}{258} \\
\hline & & & & & & & & & & & \\
\hline
\end{tabular}

Table no. 4 The importance of perception of leisure-time activities by seniors' own family

The results of these questions shows a differentiation between the two groups. We find statistically significant differences at the 0.05 level of significance ( $\mathrm{p}$-value $1.53 \times 10^{-3}$ ). While it can be argued that more seniors do not care what their families think of their activities, seniors in residential facilities do care more. This observed outcome can be attributed to the fact that for seniors in these facilities, visits and relationships with their families are more important ${ }^{9}$, and therefore also what the families think about their leisure-time activities.

Contingency coefficient $C=0.25$. Thus, there is a low dependence between the variables.

It can be concluded from the question that the elderly in residential facilities may feel in some way

\footnotetext{
${ }^{\mathbf{8}}$ The subjective perception of the word "friends" may have some influence here. Someone may therefore consider the individuals with whom they spend their free time as their acquaintances and reserve the word friend for person special to them.

${ }^{9}$ The author realizes that the phrase "more important" is not entirely appropriate.
} 
limited even restricted in their leisure-time activities by their families, they may feel limited by the fact that should their families think poorly of their activities, they might stop visiting them. This can cause them to expose themselves to the risk of social isolation.

Question: During my leisure-time, it is important to me how my friends perceive my activities (what they think about them).

\begin{tabular}{|c|c|c|c|c|c|c|c|c|c|c|c|}
\hline \multirow{3}{*}{$\begin{array}{c}\text { Seniors - } \\
\text { Domestic Environment }\end{array}$} & \multicolumn{2}{|c|}{$\begin{array}{l}\text { Definitely } \\
\text { Yes }\end{array}$} & \multicolumn{2}{|c|}{$\begin{array}{l}\text { Rather } \\
\text { Yes }\end{array}$} & \multicolumn{2}{|c|}{$\begin{array}{l}\text { Do not } \\
\text { Know }\end{array}$} & \multicolumn{2}{|c|}{$\begin{array}{l}\text { Rather } \\
\text { Not }\end{array}$} & \multicolumn{2}{|c|}{$\begin{array}{l}\text { Definitely } \\
\text { Not }\end{array}$} & \\
\hline & 11 & 7.43 & 22 & 14.86 & 15 & 10.14 & 32 & 21.62 & 68 & 45.95 & \multirow{2}{*}{148} \\
\hline & & & & & & & & & & & \\
\hline \multirow{2}{*}{$\begin{array}{c}\text { Seniors - } \\
\text { Residential Facility }\end{array}$} & \multirow{2}{*}{16} & 14.55 & \multirow{2}{*}{18} & 16.36 & \multirow{2}{*}{23} & 20.91 & \multirow{2}{*}{31} & 28.18 & \multirow{2}{*}{22} & 20.00 & \multirow{2}{*}{110} \\
\hline & & & & & & & & & & & \\
\hline \multirow[b]{2}{*}{ E } & \multirow{2}{*}{27} & 10.47 & \multirow{2}{*}{40} & 15.50 & \multirow{2}{*}{38} & 14.73 & \multirow{2}{*}{63} & 24.42 & \multirow{2}{*}{90} & 34.88 & \multirow{2}{*}{258} \\
\hline & & & & & & & & & & & \\
\hline
\end{tabular}

Table no. 5 The importance of perception of leisure-time activities by seniors' friends

In results listed in tables 4 and 5, it is particularly interesting to observe the coincidence of the frequency of responses for seniors who live at home. It was not a mere coincidence that seniors who chose the answer "definitely yes" with one question also responded this way in the second question. Certain differences can be seen in the second group, as the seniors of residential facilities mind less what their friends think about their activities than what their families do. Here, too, we find statistically significant differences between these groups of respondents at the 0.05 level of significance ( $\mathrm{p}$-value $1.10 \times 10^{-5}$ ). Contingency coefficient $\mathrm{C}=0.31$. Thus, there is a low dependence between the variables.

Thus, the results can be interpreted to mean that quite expectedly, some seniors in residential facilities are subject to certain family influence (see above).

Question: I spend my leisure time mostly by myself.

\begin{tabular}{|c|c|c|c|c|c|c|c|c|c|c|c|}
\hline \multirow{3}{*}{$\begin{array}{c}\text { Seniors - } \\
\text { Domestic Environment }\end{array}$} & \multicolumn{2}{|c|}{$\begin{array}{l}\text { Definitely } \\
\text { Yes }\end{array}$} & \multicolumn{2}{|c|}{$\begin{array}{l}\text { Rather } \\
\text { Yes }\end{array}$} & \multicolumn{2}{|c|}{$\begin{array}{l}\text { Do not } \\
\text { Know }\end{array}$} & \multicolumn{2}{|c|}{$\begin{array}{l}\text { Rather } \\
\text { Not }\end{array}$} & \multicolumn{2}{|c|}{$\begin{array}{l}\text { Definitely } \\
\text { Not }\end{array}$} & \multirow{3}{*}{148} \\
\hline & \multirow{2}{*}{12} & 8.11 & \multirow{2}{*}{16} & 10.81 & \multirow{2}{*}{28} & 18.92 & \multirow{2}{*}{54} & 36.48 & \multirow{2}{*}{38} & \multirow[t]{2}{*}{25.68} & \\
\hline & & & & & & & & & & & \\
\hline \multirow{2}{*}{$\begin{array}{l}\text { Seniors - } \\
\text { Residential Facility }\end{array}$} & \multirow{2}{*}{26} & 23.64 & \multirow{2}{*}{18} & 16.36 & \multirow{2}{*}{23} & 20.91 & \multirow{2}{*}{21} & 19.09 & \multirow{2}{*}{22} & 20.00 & \multirow{2}{*}{110} \\
\hline & & & & & & & & & & & \\
\hline \multirow{2}{*}{$\Sigma$} & \multirow{2}{*}{38} & 14.73 & \multirow{2}{*}{34} & 13.18 & \multirow{2}{*}{51} & 19.76 & \multirow{2}{*}{75} & 29.07 & \multirow{2}{*}{60} & 23.26 & \multirow{2}{*}{258} \\
\hline & & & & & & & & & & & \\
\hline
\end{tabular}

Table no. 6 Spending leisure time on one's own

We find statistically significant differences between the two groups at the 0.05 level of significance (p-value $\left.3.19 \times 10^{-4}\right)$. From these frequencies, it is clear that seniors in residential facilities prefer 
spending leisure time on their own. Contingency coefficient $C=0.27$. Thus, there is a low dependence between the variables.

This question is already quite directly related to social exclusion, or social isolation. The results cannot be simplistically interpreted so that a certain part of the seniors seek social or collective activities and the other part does not. A significant word in this question is "mostly" meaning that spending leisure time only by themselves can be independent of the seniors' will. However, we can conclude that about $1 / 4$ of the elderly are in the context of their leisure time exposed to a certain level of social isolation. A more significantly socially isolated group consists of seniors in residential facilities.

Question: I have encountered the opinion that people aged 65 and over should spend their free time mainly relaxing passively.

\begin{tabular}{|c|c|c|c|c|c|c|c|c|c|c|c|}
\hline \multirow{3}{*}{$\begin{array}{c}\text { Seniors - } \\
\text { Domestic Environment }\end{array}$} & \multicolumn{2}{|c|}{$\begin{array}{l}\text { Definitely } \\
\text { Yes }\end{array}$} & \multicolumn{2}{|c|}{$\begin{array}{l}\text { Rather } \\
\text { Yes }\end{array}$} & \multicolumn{2}{|c|}{$\begin{array}{l}\text { Do not } \\
\text { Know }\end{array}$} & \multicolumn{2}{|c|}{$\begin{array}{l}\text { Rather } \\
\text { Not }\end{array}$} & \multicolumn{2}{|c|}{$\begin{array}{l}\text { Definitely } \\
\text { Not }\end{array}$} & \multirow{3}{*}{148} \\
\hline & \multirow{2}{*}{24} & 16.22 & \multirow{2}{*}{27} & 18.42 & \multirow{2}{*}{32} & 21.62 & \multirow{2}{*}{25} & 16.89 & \multirow{2}{*}{40} & \multirow[t]{2}{*}{27.03} & \\
\hline & & & & & & & & & & & \\
\hline \multirow{2}{*}{$\begin{array}{c}\text { Seniors - } \\
\text { Residential Facility }\end{array}$} & \multirow{2}{*}{30} & 27.27 & \multirow{2}{*}{25} & 22.73 & \multirow{2}{*}{24} & 21.82 & \multirow{2}{*}{11} & 10 & \multirow{2}{*}{20} & 18.18 & \multirow{2}{*}{110} \\
\hline & & & & & & & & & & & \\
\hline \multirow{2}{*}{$\boldsymbol{\Sigma}$} & \multirow{2}{*}{54} & 20.93 & \multirow{2}{*}{52} & 20.16 & \multirow{2}{*}{56} & 21.70 & \multirow{2}{*}{36} & 13.95 & \multirow{2}{*}{60} & 23.26 & \multirow{2}{*}{258} \\
\hline & & & & & & & & & & & \\
\hline
\end{tabular}

Table no. 7 Encounters with the opinion that after the age of 65 , one should spend their free time relaxing passively

The question follows up on the previous two questions, however, not asking about the seniors' views, but if they have encountered the opinions in question. We find statistically significant differences at the 0.05 level of significance ( $p$-value $2.04 \times 10^{-2}$ ). We can therefore conclude that the elderly in residential facilities have encountered the opinion that they should spend their leisure time relaxing passively more often than seniors at home. A statistically significant difference was detected also when the results were transferred into the $2 \times 2$ contingency table.

Contingency coefficient $C=0.21$. There is a low dependence between the variables.

The observed outcome could once again be attributed to the higher average age of seniors in residential facilities and due to health restrictions.

It was deliberately not examined from whom the seniors gained the information, as this might be too personal for them. It was also not examined when they gained the information, as the answers would probably come from the plane of estimates and guesses and their outcome could not be considered relevant.

The wording of the questions came from preliminary research again and it was found that the seniors understand it in accordance with its objectives and they understand what the author wanted to find out. Passive relaxation in its essence always leads to the fact that the senior is socially isolated. We can interpret the result so that the seniors who have encountered such opinion are being fed it or such a situation is considered as desirable. 
Question: I attend events that are organized exclusively for seniors.

\begin{tabular}{|c|c|c|c|c|c|c|c|c|c|}
\hline \multirow{3}{*}{$\begin{array}{c}\text { Seniors - } \\
\text { Domestic Environment }\end{array}$} & \multicolumn{2}{|c|}{ Regularly } & \multicolumn{2}{|c|}{ Sometimes } & \multicolumn{2}{|c|}{ Seldom } & \multicolumn{2}{|c|}{ Not at all } & \multirow{3}{*}{148} \\
\hline & \multirow{2}{*}{24} & 16.22 & \multirow{2}{*}{52} & 35.14 & \multirow{2}{*}{40} & 27.03 & \multirow{2}{*}{32} & \multirow[t]{2}{*}{21.62} & \\
\hline & & & & & & & & & \\
\hline \multirow{2}{*}{$\begin{array}{c}\text { Seniors - } \\
\text { Residential Facility }\end{array}$} & \multirow{2}{*}{36} & 32.73 & \multirow{2}{*}{28} & 25.45 & \multirow{2}{*}{11} & 10 & \multirow{2}{*}{35} & 31.82 & \multirow{2}{*}{110} \\
\hline & & & & & & & & & \\
\hline \multirow{2}{*}{$\boldsymbol{\Sigma}$} & \multirow{2}{*}{60} & 23.26 & \multirow{2}{*}{80} & 31.01 & \multirow{2}{*}{51} & 19.76 & \multirow{2}{*}{67} & 25.97 & \multirow{2}{*}{258} \\
\hline & & & & & & & & & \\
\hline
\end{tabular}

Table no. 8 The frequency of visits at primarily senior events

At the beginning of the comments on the results of table no. 8, it is to be noted that seniors, who have chosen the category "not at all" consist not only of the group which is actively involved in the events for all age groups, but also of a group of people who do not engage in any events at all, or do not frequent them. We find statistically significant differences at the 0.05 level of significance ( $p$-value $1.01 \times 10^{-4}$ ). Based on these numbers and the fact that in this case the individual nominal data cannot be added up (it would have been illogical), it is not possible to decide which of these groups take part in events organized exclusively for seniors "more often". We can therefore only conclude that there is a statistically significant difference between the groups.

However, other potential presentation of results arises from the list of the frequencies. Although seniors in residential facilities have almost ideal conditions for such events, they do not use the option of such events regularly ${ }^{\mathbf{1 0}}$. The question follows up on the data in the tables above.

Question: I spend my free time at the computer.

\begin{tabular}{|c|c|c|c|c|c|c|c|c|c|c|c|}
\hline \multirow{3}{*}{$\begin{array}{c}\text { Seniors - } \\
\text { Domestic Environment }\end{array}$} & \multicolumn{2}{|c|}{ Regularly } & \multicolumn{2}{|c|}{ Sometimes } & \multicolumn{2}{|c|}{ Seldom } & \multicolumn{2}{|c|}{ Not at all } & \multicolumn{2}{|c|}{$\begin{array}{l}\text { I cannot } \\
\text { operate the } \\
\text { computer }\end{array}$} & \\
\hline & \multirow{2}{*}{13} & 8.78 & \multirow{2}{*}{16} & 10.81 & \multirow{2}{*}{28} & 18.92 & \multirow{2}{*}{20} & 13.52 & \multirow{2}{*}{71} & 47.97 & \multirow{2}{*}{148} \\
\hline & & & & & & & & & & & \\
\hline \multirow{2}{*}{$\begin{array}{c}\text { Seniors - } \\
\text { Residential Facility }\end{array}$} & \multirow{2}{*}{0} & 0 & \multirow{2}{*}{0} & 0 & \multirow{2}{*}{15} & 13.64 & \multirow{2}{*}{10} & 9.09 & \multirow{2}{*}{85} & 77.27 & \multirow{2}{*}{110} \\
\hline & & & & & & & & & & & \\
\hline \multirow{2}{*}{$\boldsymbol{\Sigma}$} & \multirow{2}{*}{13} & 5.04 & \multirow{2}{*}{16} & 6.20 & \multirow{2}{*}{43} & 16.67 & \multirow{2}{*}{30} & 11.63 & \multirow{2}{*}{156} & 60.46 & \multirow{2}{*}{258} \\
\hline & & & & & & & & & & & \\
\hline
\end{tabular}

Table no. 9 Frequency of spending leisure time at the computer

The results reported in table no. 9 really must be seen in relation to leisure time. During the preliminary research, emphasis was put exactly on whether seniors perceive the time spent at the computer as leisure time. For that reason, the answer "seldom" may not mean that seniors do not spend some

\footnotetext{
${ }^{10}$ The author is aware that the focus of such events can be decisive, but it is a major factor that such events also have the dimension of a social gathering.
} 
time at the computer every day, but that they do not understand this time as leisure.

However, it is important to highlight the high (not surprising) frequency in category "I cannot operate the computer"11.

We find statistically significant differences at the 0.05 level of significance ( $p$-value $5.81 \times 10^{-7}$ ). On the basis of these frequencies and the observed p-value, we can say that seniors at home spend their leisure time at the computer more often than seniors in residential facilities.

Contingency coefficient $C=0.34$. There is a low dependence between the variables.

Thanks to this question, the very evident potential for the development of computer competences in seniors - only on the basis of non-commercial courses, etc.

Since, as Žumárová (2010) points out, the time spent on the Internet, searching for information may open opportunities for seniors to spend their leisure time in other ways.

It would be simplistic to present the recorded data only as an opportunity. Obtaining a certain degree of computer literacy, the seniors may become addicted to computers and the Internet which may bring them not only benefits in communication, information, etc., but they can also become "isolated" from the direct interpersonal contact.

Question: Write down which leisure activities you pursue.

\begin{tabular}{|c|c|c|c|c|c|}
\hline $\begin{array}{c}\text { Seniors } \\
\text { Living in } \\
\text { Domestic } \\
\text { Environment }\end{array}$ & $\begin{array}{c}\text { Educational } \\
\text { activities }\end{array}$ & $\begin{array}{c}\text { Physical } \\
\text { leisure } \\
\text { activities }\end{array}$ & $\begin{array}{c}\text { Family leisure } \\
\text { activities }\end{array}$ & $\begin{array}{c}\text { Leisure } \\
\text { activities } \\
\text { in domestic } \\
\text { environment }\end{array}$ & $\begin{array}{c}\text { Social leisure } \\
\text { activities }\end{array}$ \\
\hline $\begin{array}{c}\text { Educational } \\
\text { activities }\end{array}$ & 178 & 56 & 0 & 41 & 17 \\
\hline $\begin{array}{c}\text { Physical } \\
\text { leisure } \\
\text { activities }\end{array}$ & 56 & 101 & 0 & 25 & 10 \\
\hline $\begin{array}{c}\text { Family Leisure } \\
\text { Activities }\end{array}$ & 0 & 0 & 35 & 16 & 0 \\
\hline $\begin{array}{c}\text { Leisure } \\
\text { activities } \\
\text { in domestic } \\
\text { environment }\end{array}$ & 41 & 25 & 16 & 98 & 0 \\
\hline $\begin{array}{c}\text { Social leisure } \\
\text { activities }\end{array}$ & 17 & 10 & 0 & 0 & 85 \\
\hline
\end{tabular}

Table no. 10a Leisure-time activities of the elderly living at home

\footnotetext{
${ }^{11}$ This was explained especially for the elderly in residential facilities by the workers - some seniors are afraid to work with the computer or it is too complex for them to understand how the internet works.
} 
In the context of the assessment of this question, no exhaustive list of all detected leisure-time activities is presented but the results are organized according to the above categorization of leisure-time activities. Due to the fact that it was an open question the total frequency does not match the number of respondents ${ }^{12}$.

The question was deliberately not asked to mean: How do you spend your leisure time? Otherwise, there would have to be unsolicited correction with the theoretical definition of leisure time. Another reason was that the seniors should regard the named activities as leisure time activities.

Two of the listed activities were unclassifiable. It was photography and sleep ${ }^{13}$. One response was: "anything I can manage to do."14

Individual leisure-time activities were divided according to own categorization of leisure-time activities. The combinations of the individual categories were created according to the key whose sample is given below:

1. Watching documentaries on WWII = leisure-time activity in domestic environment + educational activity.

2. Tourist trips $=$ physical leisure-time activity + educational activity.

3. Dance performances at balls $=$ social activity + physical leisure-time activity.

4. Attendance at balls $=$ social activity + physical leisure-time activity .

5. Exercise in front of the TV = leisure-time activity in domestic environment + physical leisure-time activity.

The above are only examples. Some activities had to be left only in one category. It was for example the activity of watching tv - if it is not specified, as in the example above, it was not clear what programs the senior watches. The same way, in case of leisure-time activities with the family - unless otherwise specified, the activity was included only in the given category (e.g. playing with the grandchildren). Marginal frequencies are deliberately not listed as they would have presented misleading data if the activity fell into just one leisure-time activity category.

Seniors living at home reported a total of 497 leisure-time activities (with a high degree of conformity). Only 2 seniors have said that they do not pursue any activity (however, they are bound to spend their leisure time in some way). The above table shows that the category of highest frequency is the category of educational activities. However, it is to be noted that most of the mentioned activities fall into the category of informal education.

From the whole of the table, we need to draw attention in particular to the category family leisure activities which has the lowest frequency. That can be explained in two ways. The logical one is that seniors do not spend their leisure time with their families. The other is that they do not consider time spent with their families as leisure-time activity.

It clearly and positively follows from the table that 399 of the 497 leisure-time activities are carried out outside the dwelling area of the seniors. The author considers this as the most important

\footnotetext{
${ }^{12}$ A total of 11 respondents reported that they do not pursue any activity.

${ }^{13}$ Sleep cannot be seen as a leisure-time activity, even though it could logically falls into the category of leisure-time activities in the domestic environment.

${ }^{14}$ The senior who gave this answer listed "physical" as their favourite leisure-time activity.
} 
finding, particularly in regard to creating the conditions for such spending of leisure times by seniors, and, at the same time, with reference to the focus of the paper.

On the contrary, a negative finding for the author was that not a single senior indicated any volunteering activity.

At the same time, the author draws attention to the fact that the frequencies listed must be confronted with the previous responses from the seniors concerning physical leisure-time activities. The second highest frequency listed here is caused by physically active seniors who listed 2 or more such activities.

\begin{tabular}{|c|c|c|c|c|c|}
\hline $\begin{array}{c}\text { Seniors } \\
\text { Living in } \\
\text { Residential } \\
\text { Environment }\end{array}$ & $\begin{array}{c}\text { Educational } \\
\text { activities }\end{array}$ & $\begin{array}{c}\text { Physical } \\
\text { leisure } \\
\text { activities }\end{array}$ & $\begin{array}{c}\text { Family leisure } \\
\text { activities }\end{array}$ & $\begin{array}{c}\text { Leisure } \\
\text { activities } \\
\text { in domestic } \\
\text { environment }\end{array}$ & $\begin{array}{c}\text { Social leisure } \\
\text { activities }\end{array}$ \\
\hline $\begin{array}{c}\text { Educational } \\
\text { activities }\end{array}$ & 38 & 13 & 0 & 13 & 0 \\
\hline $\begin{array}{c}\text { Physical } \\
\text { leisure } \\
\text { activities }\end{array}$ & 13 & 69 & 0 & 15 & 26 \\
\hline $\begin{array}{c}\text { Family Leisure } \\
\text { Activities }\end{array}$ & 0 & 0 & 36 & 25 & 0 \\
\hline $\begin{array}{c}\text { Leisure } \\
\text { activities } \\
\text { in domestic } \\
\text { environment }\end{array}$ & 13 & 15 & 25 & 71 & 0 \\
\hline $\begin{array}{c}\text { Social leisure } \\
\text { activities }\end{array}$ & 0 & 26 & 0 & 0 & 65 \\
\hline
\end{tabular}

Table no. 10b Leisure-time activities of the elderly living in residential facilities

Seniors living in residential facilities reported a total of 279 leisure-time activities (with a high degree of conformity). A total of 9 respondents reported that they do not pursue anything. The above table shows that the category of highest frequency is the category of leisure-time activities in domestic environment.

As well as in the table dealing with the other group of seniors, the lowest frequency is surprisingly in the category of "family leisure activities", for the same reason as listed above.

Again, it can be valued positively that the seniors stated 208 of 279 activities that are carried out outside of their dwelling area, but generally in the context of the given facility or very nearby.

If we compare both tables, there is quite an evident difference in the category "educational activities". 
Question: Which of your leisure-time activities do you consider as your favourite one.

The inclusion of this question resulted from the fact that people usually spend their leisure time performing more activities but favouring one, or considering it as the most favourite. Such a preferred activity can be significantly seasonal (e.g., skiing, cycling, etc.). At the same time, such a decision may be subjectively complex. The intention of the author was to confront the results of this question with the results of the previous one.

A positive finding is that only two of the seniors stated as their favourite leisure-time activity what may be described as extremely passive or negative activity. It was going to pubs and sleeping. A significant part of the seniors responded "I do not know", as they could not decide. A total of 11 seniors ( 9 from residential facilities, and 2 from domestic environment) stated nothing, but in the previous question, they also answered that they do not have any leisure-time activities. Their failure to answer this question is actually a more than clear answer.

The results in the following table are arranged only by the primary association with specified categories.

\begin{tabular}{|c|c|c|c|c|c|c|c|c|c|c|c|}
\hline & \multicolumn{2}{|c|}{$\begin{array}{l}\text { Educa- } \\
\text { tional } \\
\text { activities }\end{array}$} & \multicolumn{2}{|c|}{$\begin{array}{l}\text { Physical } \\
\text { leisure } \\
\text { activities }\end{array}$} & \multicolumn{2}{|c|}{$\begin{array}{c}\text { Family } \\
\text { leisure } \\
\text { activities }\end{array}$} & \multicolumn{2}{|c|}{$\begin{array}{c}\text { Leisure } \\
\text { activities in } \\
\text { domestic } \\
\text { environmen }\end{array}$} & \multicolumn{2}{|c|}{$\begin{array}{c}\text { Social } \\
\text { leisure } \\
\text { activities }\end{array}$} & \\
\hline \multirow{2}{*}{$\begin{array}{c}\text { Seniors - } \\
\text { Domestic Environment }\end{array}$} & \multirow{2}{*}{34} & 23.29 & \multirow{2}{*}{66} & 45.21 & \multirow{2}{*}{10} & 6.85 & \multirow{2}{*}{21} & 14.38 & \multirow{2}{*}{15} & 10.27 & \multirow{2}{*}{146} \\
\hline & & & & & & & & & & & \\
\hline \multirow{2}{*}{$\begin{array}{c}\text { Seniors - } \\
\text { Residential Facility }\end{array}$} & \multirow{2}{*}{3} & 2.97 & \multirow{2}{*}{37} & 36.63 & \multirow{2}{*}{21} & 20.79 & \multirow{2}{*}{11} & 10.89 & \multirow{2}{*}{29} & 28.71 & \multirow{2}{*}{101} \\
\hline & & & & & & & & & & & \\
\hline \multirow{2}{*}{$\boldsymbol{\Sigma}$} & \multirow{2}{*}{37} & 14.98 & \multirow{2}{*}{103} & 41.70 & \multirow{2}{*}{31} & 12.55 & \multirow{2}{*}{32} & 12.96 & \multirow{2}{*}{44} & 17.81 & \multirow{2}{*}{247} \\
\hline & & & & & & & & & & & \\
\hline
\end{tabular}

Table no. 11 The most favourite leisure-time activity of seniors

Table no. 11 for both groups clearly identifies as favourite activities "physical leisure activities", although their popularity is more dominant in relation to other categories of leisure-time activities among elderly people living at home.

Statistically significant differences between these groups of respondents and popularity of the ways of spending leisure time were detected at the 0.05 level of significance ( $p$-value $1.29 \times 10^{-10}$ ). This significant result can be attributed particularly to the categories of "educational activities", "physical leisure activities" and "social leisure activities".

Thus, we can conclude that both groups prefer different leisure-time activities. The result is influenced by several factors: offer and availability of activities, age, state of health, motivation and own interest.

Contingency coefficient $C=0.42$. Thus, there is a medium dependence between the variables.

As already indicated above, physical movement constitutes a proof of the seniors' autonomy and independence to them, a proof that "the are living".

Question: What facilities (organization) dedicated to the organization of leisure-time activities for people aged 65 years and more do you visit. 
With this question, the group of seniors in residential facilities were relatively predictable in their responses. Not one senior from 110 reported spending leisure time outside the given facility. Some seniors mentioned a club, however, even those were organized within the facility. The result, however, cannot be interpreted so that all seniors would be involved in the leisure-time activities on offer (see also the results above).

Seniors living in a domestic environments offered a much more heterogeneous enumeration of facilities (organisations). Some organizations had to be excluded by the author on the grounds that they were not organizations whose target group would be the elderly exclusively but they were accessible to everybody, even though it was possible to assume (not assert conclusively) that the age composition of the members would meet the conditions of this paper.

A total of 91 senior citizens stated at least one organization. A total of 21 respondents reported attending third-age university. The highest frequency was listed for the seniors' club (pensioners' or similar names), this option was reported by 75 seniors. A specific category was comprised of organizations that exist in a kind of "unofficial" form, so they do not have the status of seniors' clubs or other. This option was reported by 31 seniors.

Question: I would like to spend my leisure time doing other activities as well, but such activities are too expensive (theatre, concerts, etc.).

\begin{tabular}{|c|c|c|c|c|c|c|c|c|c|c|c|}
\hline \multirow{3}{*}{$\begin{array}{c}\text { Seniors - } \\
\text { Domestic Environment }\end{array}$} & \multicolumn{2}{|c|}{$\begin{array}{l}\text { Definitely } \\
\text { Yes }\end{array}$} & \multicolumn{2}{|c|}{$\begin{array}{l}\text { Rather } \\
\text { Yes }\end{array}$} & \multicolumn{2}{|c|}{$\begin{array}{l}\text { Do not } \\
\text { Know }\end{array}$} & \multicolumn{2}{|c|}{$\begin{array}{l}\text { Rather } \\
\text { Not }\end{array}$} & \multicolumn{2}{|c|}{$\begin{array}{l}\text { Definitely } \\
\text { Not }\end{array}$} & \\
\hline & 37 & 25.00 & 43 & 29.05 & 12 & 8.11 & 10 & 6.76 & 46 & 31.08 & \multirow[t]{2}{*}{148} \\
\hline & & & & & & & & & & & \\
\hline \multirow{2}{*}{$\begin{array}{c}\text { Seniors - } \\
\text { Residential Facility }\end{array}$} & \multirow{2}{*}{35} & 31.82 & \multirow{2}{*}{24} & 21.82 & \multirow{2}{*}{17} & 15.45 & \multirow{2}{*}{19} & 17.27 & \multirow{2}{*}{15} & 13.64 & \multirow{2}{*}{110} \\
\hline & & & & & & & & & & & \\
\hline \multirow[t]{2}{*}{$\boldsymbol{\Sigma}$} & \multirow{2}{*}{72} & 27.91 & \multirow{2}{*}{67} & 25.97 & \multirow{2}{*}{29} & 11.24 & \multirow{2}{*}{29} & 11.24 & \multirow{2}{*}{61} & 23.64 & \multirow{2}{*}{258} \\
\hline & & & & & & & & & & & \\
\hline
\end{tabular}

Table no. 12 Financial obstacles to the realization of leisure-time activities

The evaluation of the data in table no. 12 can be done on the basis of threefold approach. We find statistically significant differences between the groups at the 0.05 level of significance (p-value $\left.1.68 \times 10^{-4}\right)$. However, if we use the chi-squared distribution for the $2 \times 2$ contingency table in which both groups are maintained, but we add up the frequencies in the categories "definitely yes" and "rather yes" in comparison to the sums in the categories "rather not" and "definitely not", we come to the conclusion that there are no statistically significant differences on the level of significance 0.05 ( $\mathrm{p}$-value of $4.82 \times 10^{-1}$ ). However, if we make adjustments to the $2 \times 2$ contingency table, including only categories "definitely yes" and "definitely not", statistically significant differences on the level of significance 0.05 can be detected ( $p$-value of $4.37 \times 10^{-3}$ ).

Based on the frequency and additional statistical calculation, it can be concluded that the seniors in residential facilities would more likely wish to have other activities, which they cannot afford for financial reasons, nevertheless.

Even if it is not possible to exclude other intervening variables, the cost of leisure-time activities can lead to social isolation of seniors by seeking cheaper substitutes, etc. 
Question: The old-age retirement changed my life negatively in financial terms.

\begin{tabular}{|c|c|c|c|c|c|c|c|c|c|c|c|}
\hline \multirow{3}{*}{$\begin{array}{c}\text { Seniors - } \\
\text { Domestic Environment }\end{array}$} & \multicolumn{2}{|c|}{$\begin{array}{l}\text { Definitely } \\
\text { Yes }\end{array}$} & \multicolumn{2}{|c|}{$\begin{array}{l}\text { Rather } \\
\text { Yes }\end{array}$} & \multicolumn{2}{|c|}{$\begin{array}{l}\text { Do not } \\
\text { Know }\end{array}$} & \multicolumn{2}{|c|}{$\begin{array}{l}\text { Rather } \\
\text { Not }\end{array}$} & \multicolumn{2}{|c|}{$\begin{array}{l}\text { Definitely } \\
\text { Not }\end{array}$} & \multirow{3}{*}{148} \\
\hline & \multirow{2}{*}{51} & 34.46 & \multirow{2}{*}{56} & 37.84 & \multirow{2}{*}{6} & 4.05 & \multirow{2}{*}{10} & 6.76 & \multirow{2}{*}{25} & \multirow[t]{2}{*}{16.89} & \\
\hline & & & & & & & & & & & \\
\hline \multirow{2}{*}{$\begin{array}{c}\text { Seniors - } \\
\text { Residential Facility }\end{array}$} & \multirow{2}{*}{21} & 19.09 & \multirow{2}{*}{18} & 16.36 & \multirow{2}{*}{15} & 13.64 & \multirow{2}{*}{25} & 22.73 & \multirow{2}{*}{31} & 28.18 & \multirow{2}{*}{110} \\
\hline & & & & & & & & & & & \\
\hline \multirow{2}{*}{$\boldsymbol{\Sigma}$} & \multirow{2}{*}{72} & 27.91 & \multirow{2}{*}{74} & 28.68 & \multirow{2}{*}{21} & 8.14 & \multirow{2}{*}{35} & 13.56 & \multirow{2}{*}{56} & 21.71 & \multirow{2}{*}{258} \\
\hline & & & & & & & & & & & \\
\hline
\end{tabular}

Table no. 13 Negative financial impact on life upon retirement

We find statistically significant differences between these groups at the 0.05 level of significance (p-value $\left.3.57 \times 10^{-9}\right)$. We can therefore conclude that for seniors in residential facilities for the elderly, retirement did not bring financially negative changes.

Contingency coefficient is $C=0.39$. There is a low dependence between the variables.

As almost all of the questionnaires (in residential facilities) were filled out together with the seniors in person, the author also received information that explain the observed outcomes. One of the factors is that seniors there do not worry about existential problems associated with housing, ensuring food, energy, etc. Therefore, even if the remaining old-age pension after paying the facility may be relatively low, they can manage almost the way they want (not in specific cases).

Question: On a monthly basis, I am willing to spend for my leisure-time activities.

\begin{tabular}{|c|c|c|c|c|c|c|c|c|c|}
\hline \multirow{3}{*}{$\begin{array}{c}\text { Seniors - } \\
\text { Domestic Environment }\end{array}$} & \multicolumn{2}{|c|}{$\begin{array}{l}\text { Up to } 500 \\
\text { CZK }\end{array}$} & \multicolumn{2}{|c|}{$\begin{array}{c}501-1,000 \\
\text { CZK }\end{array}$} & \multicolumn{2}{|c|}{$\begin{array}{c}\text { 1,001-1,500 } \\
\text { CZK }\end{array}$} & \multicolumn{2}{|c|}{$\begin{array}{l}\text { More than } \\
\mathbf{1 , 5 0 0 ~ C Z K}\end{array}$} & \multirow{3}{*}{148} \\
\hline & \multirow{2}{*}{135} & 91.22 & \multirow{2}{*}{8} & 5.40 & \multirow{2}{*}{5} & 3.38 & \multirow{2}{*}{0} & \multirow[t]{2}{*}{0.00} & \\
\hline & & & & & & & & & \\
\hline \multirow{2}{*}{$\begin{array}{c}\text { Seniors - } \\
\text { Residential Facility }\end{array}$} & \multirow{2}{*}{104} & 94.55 & \multirow{2}{*}{6} & 5.45 & \multirow{2}{*}{0} & 0.00 & \multirow{2}{*}{0} & 0.00 & \multirow{2}{*}{110} \\
\hline & & & & & & & & & \\
\hline \multirow{2}{*}{$\boldsymbol{\Sigma}$} & \multirow{2}{*}{239} & 93.63 & \multirow{2}{*}{14} & 5.43 & \multirow{2}{*}{5} & 1.94 & \multirow{2}{*}{0} & 0.00 & \multirow{2}{*}{258} \\
\hline & & & & & & & & & \\
\hline
\end{tabular}

Table no. 14 Amount of own investments in leisure-time activities per month

With the results in table no. 14, the conditions for the usage of Pearson's chi-squared test for contingency table were not met. From the absolute frequency, we may infer that seniors do not want to or cannot invest too much of their finances in their leisure-time activities. For obvious reasons, the material status of individual seniors was not ascertained, however in some cases it was obvious that this is rather a question of setting priorities in the life of a senior and of the confrontation of the value ladder with the actual value orientation ${ }^{15}$.

\footnotetext{
${ }^{15}$ On the basis of personal meetings with the elderly, it was revealed that seniors spend much more money on "things" they do not need for their life (alcohol, cigarettes, etc.).
} 
Let us mention at this question a claim of the utopian socialists Robert Owen who pioneered the idea of albeit minimum but still some financial participation of people on leisure activities. If such an activity is for free, it is in Owen's words worth nothing (Štverák, 1983).

Question: What leisure activities would you like to do but for some reason you cannot (please give a specific reason).

This again is not accompanied by an exhaustive list of all the activities the seniors stated. However, they can be classified into two groups.

The first group consists of physical leisure activities that seniors can no longer carry out due to health limitations (trips, cycling, swimming, but also volleyball was listed).

The second group is made up of activities that are too costly to the seniors (theater, concerts).

Not one of the seniors submitted a combination of the two limiting factors or other factors. In the table below, the total frequency of respondents is lower than their total number (258). A total of 60 respondents chose the possibility "do not know".

\begin{tabular}{|c|c|c|}
\hline & Health reasons & Financial reasons \\
\hline $\begin{array}{c}\text { Seniors - } \\
\text { Domestic Environment }\end{array}$ & 51 & 48 \\
\hline $\begin{array}{c}\text { Seniors - } \\
\text { Residential Facility }\end{array}$ & 69 & 30 \\
\hline $\boldsymbol{\Sigma}$ & 120 & 78 \\
\hline
\end{tabular}

Table no. 15 Financial obstacles to the realization of leisure-time activities

The results in tables 12 to 15 point to the fact that the elderly are in financial terms an endangered group. Based on the nature of the research, their overall social situation has not been screened, nevertheless, the financial limitations of leisure-time activities point to possible reduction of quality of life in connection with the limited options of spending free time. The author realizes that seniors who regularly wants to spend the holiday in the Maldives cannot expect to have it reimbursed from the state budget, but with much cheaper leisure time activities, some aid should exist.

However, we may not omit the question whether seniors seek cheaper alternatives, actively using (or knowing of) discounts offered by the institutions (swimming pools, museums, theatres, etc.) as a bonus resulting from their age. For the elderly in residential facilities, distorted ideas about real prices of goods and services may play a role.

In conclusion, however, it can be stated that the financial limits on the field of leisure-time activities lead to social exclusion of the elderly and their social isolation.

Question: What leisure activities would you like to do more but you consider their offer as insufficient. The author considers the answers to this question as the most surprising. Not only that, they were identical in all cases in both of the groups surveyed, but especially none of the respondents stated an activity (activities), whose offer he or she would consider insufficient. 
In this context, the following answer by a senior lady (aged 79) seems cogent: "It would suffice to actually do those things on offer."

The above mentioned compliance can be attributed to several factors, but without any proof of direct causality. Therefore, stating them would be a speculative conclusion derived from this question ${ }^{16}$. Certainly, the stated result leads to considerations of the existence of opportunities for leisure-time activities of the elderly.

Question: What shortcomings (obstacles, problems, etc.) do you think there are in carrying out leisure-time activities for people aged 65 years and more that you perceive from the perspective of the society, place of residence, the younger age groups, etc. (e.g. illness, finance, transport, lack of opportunities, etc.) ${ }^{17}$.

The results of this question need to be compared with the previous question. The dominant obstacle was health; in the case of illness, the elderly were in a way leisurely but also the socially isolated ${ }^{18}$. The overall match of the total frequencies in the category "health" is surely interesting. Again, a significant part of seniors (of both groups) replied that they do not know. A total of 75 seniors gave this answer. In the table of frequencies below, all obstacles are listed. The category of obstacles denoted in the table as "technical problems" includes answers which were in essence similar to: "nowadays it is all about computers." The said category is questionable from the perspective of the author, mainly because seniors did not state any leisure-time activities which they would like to perform and which they could not perform due to a certain technical obstacle.

\begin{tabular}{|c|c|c|c|c|c|c|c|c|c|}
\hline & \multicolumn{2}{|c|}{ Health } & \multicolumn{2}{|c|}{ Finance } & \multicolumn{2}{|c|}{$\begin{array}{l}\text { Technical } \\
\text { problems }\end{array}$} & \multicolumn{2}{|c|}{ Shipping } & \\
\hline \multirow{2}{*}{$\begin{array}{c}\text { Seniors - } \\
\text { Domestic Environment }\end{array}$} & \multirow[t]{2}{*}{68} & 60.18 & \multirow[t]{2}{*}{22} & 19.47 & \multirow[t]{2}{*}{8} & 7.08 & \multirow[t]{2}{*}{15} & 13.27 & \multirow{2}{*}{113} \\
\hline & & & & & & & & & \\
\hline \multirow{2}{*}{$\begin{array}{c}\text { Seniors - } \\
\text { Residential Facility }\end{array}$} & \multirow{2}{*}{52} & 61.18 & \multirow{2}{*}{19} & 22.35 & \multirow{2}{*}{10} & 11.76 & \multirow{2}{*}{4} & 4.71 & \multirow{2}{*}{85} \\
\hline & & & & & & & & & \\
\hline \multirow{2}{*}{$\boldsymbol{\Sigma}$} & \multirow{2}{*}{120} & 60.61 & \multirow{2}{*}{41} & 20.71 & \multirow{2}{*}{18} & 9.09 & \multirow{2}{*}{19} & 9.59 & \multirow{2}{*}{198} \\
\hline & & & & & & & & & \\
\hline
\end{tabular}

Table no. 16 Perceived obstacles to the realization of leisure-time activities

We do not find statistically significant differences between the groups of seniors at the 0.05 level of significance (p-value 0.17).

\footnotetext{
${ }^{16}$ The referred compliance can be attributed to: "Seniors having no idea how one's leisure time can be spent (do not know about the options). They are not interested in these activities (therefore do not lack their offer, which is therefore lower based on the demand). They have no wishes in the field of leisure time. The use of the Internet to search for a variety of possible leisure activities for the elderly is generally low. The offer is not satisfactory."

${ }^{17}$ In the preliminary research, it was verified that illness was perceived as a barrier by seniors in the sense that illness rules them out of certain leisure activities without adequate alternatives. Therefore, they perceived it as a barrier from the perspective of the society, the way the author meant the question. After the preliminary research, possible alternatives were included in the answer to this question. From this perspective, the question may seem indicative. In relation to other questions, the author dares to argue that it is not indicative.

${ }^{18}$ Naturally, even the younger age-groups are excluded from certain activities. In the case of long-term (lifelong) illnesses, however, they have greater opportunities to participate in recreational activities designed for them.
} 
Question: I actively participate in organizing leisure-time activities (if so, indicate which). This question was included after the preliminary research and on the basis of the responses to the questionnaire from the elderly living at home.

The question pursued the particular level and rate of participation in leisure-time activities for their peers, neighbourhood, etc. It should be noted that the preparation and the organisation itself already are leisure-time activities (although no senior included such leisure-time activity in their enumeration) ${ }^{19}$.

Seniors, who answered in the affirmative, that is, who are actively involved in organizing recreational activities, carried out their activities within a seniors' (pensioners') club, not only for the members of the club, but for other target group as well (in this case, it was cultural performances balls or other cultural and social events). Seniors who are engaged in cultural performances came from villages rather than towns. A total of 26 seniors from the domestic environment reported that they are in some way involved in the leisure-time activities mentioned above.

Seniors from residential facilities did not participate on active organization of leisure-time activities to the same extent as the seniors from the domestic environment. This also follows from the results of the Pearson's chi-squared test for the $2 \times 2$ contingency table recording the confidence level of 0.05 ( $p$-value of 0.39). This means that there is no statistically significant difference between the groups of older people and their active involvement in the implementation of leisure-time activities. Leisure-time activities reported were in all cases related to activities within the facility. For instance, these were activities connected with the celebration of one of the clients' birthday or cultural performances on the occasion of some important days of the year. A total of 15 seniors from residential facilities said that they are in some way involved in the recreational activities mentioned above.

Question: What leisure activities could you according to your experience and skills co-organize? The result of this question corresponds firstly with the career the seniors performed and secondly with leisure-time activities they used to do before reaching senior age. In the case of the part of seniors who filled out the questionnaire on their own, their current state of health manifested itself ${ }^{20}$. Only one female senior stated and activity which was primarily targeted to only one target group. She stated that she worked in a kindergarten and could therefore "play" with children. Overall, however, only 71 seniors (45 from the domestic environment, and 26 from residential facilities) chose a leisure-time activity which they could co-organize.

The wording of the question which was tested in preliminary research was also important, meaning the fact that it was not decisive whether the senior is currently working actively on organizing leisure-time activities. Even seniors who answered the previous question in the affirmative reported "nothing" in response to this one. Also, the structure of activities mentioned changed significantly. A total of 60 seniors reported some physical leisure-time activity (exercise, volleyball, hiking, trips), 8 seniors reported some social activities (musical performances, games), 2 seniors chose educational activities (a discussion about their experiences of travel) and one female senior stated work with children. None of the seniors mentioned more than one activity.

\footnotetext{
${ }^{19}$ It is basically certain that some seniors are actively involved in organizing recreational activities, but they do not "recognize" this activity as such. Even planning a trip can be considered as an activity falling within this category.

${ }^{20}$ Some did not take their current state of health into account.
} 
Question: I have encountered negative behaviour towards my person (insults, ridicule, etc.) because of being aged 65 years and over (if yes, please specify).

Although the concept of ageism (not meaning juvenile ageism) is often mentioned in the media, professional literature, etc., the question on this aspect presents some positive findings, although probably not applicable as reflecting the true state of the society, or the Opava region reality ${ }^{21}$.

Only 3 out of 258 seniors ( 1 from a residential facility and 2 from domestic environment) met with negative behaviour to them on the grounds of their age. In all cases, this involved slurs or insults. The reasons justifying the outcome of this question are only speculative. The author is inclined to the view that the outcome of this question cannot be generalized and it is significantly affected by a certain degree of "coincidence". Alternatively, the seniors displace negative experience from their memories or do not perceive it as such.

\section{Conclusion}

Although the results cannot be considered positive, negative, or alarming in any particular way, they do carry relevance in connection to the topic of this paper.

The ascertained results show that the part of seniors with whom it would be possible to monitor signs of social exclusion, have reached this state voluntarily. Comparing the two groups, it was predictable that seniors in residential facilities would generally be less active, based on the more advanced age, etc., however, their leisure time is more individual, although they can meet other seniors through leisure activities organized by their facilities, but of course, through other unorganized activities as well. The author, however, does not believe that the solution should be a so-called. deinstitutionalization, as residential facilities for seniors occupy a firm position in the society. The proposed solutions are based on three levels.

1. Raising awareness - this means developing and supporting various sources of information on effectuated and possible leisure-time activities for seniors. Specifically: mandatory website updates (municipalities, associations, etc. ${ }^{22}$ and accumulation of information under a single source of information in various forms (internet, printed media).

2. Motivation - this means on the theoretical plane to develop methods and tools applicable to motivate seniors to carry out appropriate leisure-time behaviour. Motivation, however, is more of a psychological matter. It is clearly connected with the development of human resources, i.e. workers for whom seniors are a target group to work with.

3. Pre-Senior Education - preparation for old age. This falls within the area of adult education. In the case of pre-senior education, it should primarily focus on education for ways of spending leisure time. This suggestion is closely related to motivation. Only one specific way is not to be supported as the correct one (see deinstitutionalization).

\footnotetext{
${ }^{21}$ Seniors in residential facilities sounded quite unambiguous, i.e. their voice and behaviour hinted that their response was genuine and they were not afraid to tell the truth.

${ }^{22}$ For example, a home for the elderly has changed its name and website link during its existence. It is possible to find three different websites to one home for the elderly (all making the impression of being up-to-date). Furthermore, one organization offered some educational courses (in 2011), when asked whether the courses continue, the worker in charge replied that they never existed and do not continue.
} 
In terms of leisure-time behaviour, seniors form in the context of social exclusion an undoubtedly vulnerable group, but rather due to their own personal approach. Nevertheless, the influence of the society is considerable, especially in the creation and accessibility of leisure-time activities for groups of seniors who feel limited (restricted) in their leisure time.

\section{References}

Co je sociální vyloučení. [What is Social Exclusion]. [online]. Accessed $9^{\text {th }}$ September 2015. http:// www.socialni-zaclenovani.cz/co-je-socialni-vylouceni.

Janiš, K. Jr. (2011). Volný čas seniorů. [Seniors' Leisure Time]. In Aktuální problémy pedagogiky ve výzkumech studentů doktorských studijních programů VIII. [Contemporary Issues of Pedagogy in Ph.D. Students' Researches VIII.] (pp. 693-700). Olomouc: Univerzita Palackého v Olomouci.

Janiš, K. Jr. (2012). Senior a změny v seniorském věku. [A Senior and Changes in the Senior Age]. In J. Ondráková et al., Vzdělávání seniorů a jeho specifika [Senior Education and Its Specifics] (pp. 11-32). Červený Kostelec: Pavel Mervart. (a)

Janiš, K. Jr. (2012). Volný čas jako prostředek ke zlepšení mezigeneračních vztahů. [Leisure Time Leisure as a Means to Enhance Intergenerational Relationships]. Prevence, 9(2), 10-11. (b)

Janiš, K. Jr. (2012). Volný čas seniorů v zařízeních sociální péče ve srovnání s volným časem seniorů žijících v domácím prostředí. [Leisure Time of Seniors in Social Care in Comparison with the Leisure Time of Seniors Living at Home]. In Od teorie k praxi od praxe k teorii [From Theory to Practice and from Practice to Theory] (pp. 194-202). Hradec Králové: Gaudeamus. (c)

Janiš, K. Jr. (2012). Volný čas jako prostředek zvýšení pohybové aktivnosti a prevence ageismu. [Leisure Time as a Means of Increasing Physical Activity and Prevention of Ageism]. In Juvenilia Paedagogica (pp. 108-112). Trnava: Trnavská univerzita, PdF. (d)

Janiš, K. Jr. (2014). Volný čas seniorů. [Seniors' Leisure Time]. (Disertační práce). Olomouc: PdF UP v Olomouci.

Mareš, P., \& Sirovátka, T. (2008). Sociální vyloučení (exkluze) a sociální začlenování (inkluze) koncepty, diskurz, agenda. [Social Exclusion and Social Inclusion - Concepts, Discourse, Agenda]. Sociologický časopis / Czech Sociological Review, 44(2), 271-294.

\section{Author}

Mgr. Kamil Janiš, Ph.D.

Faculty of Public Policies, Silesian University in Opava

The Institute of Pedagogical and Psychological Sciences

Bezručovo náměstí 885/14, 746 01, Opava, Czech Republic

kamil.janis@fvp.slu.cz 